DOI 10.31558/2519-2949.2021.3.7

УДК 323/32.019.5/659.4

ORCID ID: https://orcid.org/0000-0002-1055-1629

Новицький О. О., Південноукрайнський національний педагогічний університет ім. К. Д. Уиинського

\title{
ФОРМУВАННЯ ТА ПРОЯВИ ПОЛІТИЧНОГО ТРИГЕРУ «КРИМ»
}

Стаття присвячена дослідженню формування та проявів політичного тригеру «Крим». Представлена історично-иіннісна характеристика подій 2014 року. Безпосередньо увага стосується аналізу категоріальної бази, зокрема, виокремлюються поняття тригер, політичний тригер, дискурс, види дискурсу. В статті представлене розуміння статусу Криму в різних дискурсах: сакральному та профанному. Акиентується увага на асоиіативних зв'язках та інтерпретачії в медіатекстах. Визначено, щзо тригер-аналіз в подальшому є корисним при дослідженні протиборчих дискурсів, оскільки иіннісні тригери будуть з'являтися все частіше. 3'ясовано, що історичні події є найбільш уживаними інтерпретаціями в сакральному дискурсі. Більшість «сакральних» текстів містять в собі ті чи інші посилання на історичний контекст.

Визначено, що рух мережевих спільнот за межі віртуальності та перетворення їх в повноцінних політичних акторів залежить від їх розмірів (малі спільноти легше організовуються), а також від інтерпретаційного потенціалу того чи іншого иіннісно-політичного тригеру. Чим більше в тригері закладено саме політичного, тим меншою є ймовірність реалізації сценарію виведення спільноти за межі віртуальності. І навпаки, якщьо в тригері, крім політичного, закладений потенціал для конфліктної інтерпретації, що звертається до вищих ідентичностей, тим більшою є ймовірність організаџї малих мережевих спільнот як політичних акторів.

Обтрунтовано, що боротьба дискурсів між собою не призводить до повноцінної перемоги одного з них. Кожен дискурс встановлює певні значення в свідомості індивідів та колективній свідомості спільнот. Всередині сакрального дискурсу існує власний сакрально-профанний дискурс. У той же час констатовано, що поза профанним дискурсом існування політики вкрай утруднене.

Ключові слова: тригер, ЗМІ, Крим, окупачія, анексія, політика, суспільство, політичний тригер.

Постановка проблеми у загальному вигляді. Відносини між Україною та Росією є історично довгими та спірними. Практично завжди Росія прагне до розширення Російської імперії, чи то до створення Радянського Союзу (чи якось іншого), наприклад, у вигляді Російської Федерації. Позиція Росії в цих всіх відносинах $є$ встановлення будь-яких перепон на шляху побудови Україною незалежної держави, рівноправного члена європейської співдружності націй. Анексія Криму стала такою відправною точкою в політичному процесі України, яка змінила не тільки географічні простори України, алей змінила свідомість, риторику опису цих процесів, і по суті, ця подія стала тригером розвитку подальших політичних подій в світі. «Зовнішня агресія Росії, результатом якої стала втрата Україною Криму оголила ряд серйозних економічних проблем і одночасно породила нові. Після виснажливого протистояння на Майдані і боротьби з режимом Януковича, яке здійснило негативний вплив на економічну ситуацію, анексія Криму і існуюча можливість військового вторгнення Росії в південно-східну Україну стала своєрідним апофеозом гострої активізації цілого букету економічних загроз» [6]. «Довга і повзуча анексія Криму почалася задовго до 2014 року. Росія готувалась до цього кроку з 1992 року. Тоді Верховна рада Росії визнала указ президії Верховної ради СРСР 1954 року, яким Крим було включено до складу Української РСР, таким, що не має юридичної сили» [8].

Свою позицію висловив під час неформального засідання в ООН по Криму за формулою «Арріа» представник Великої Британії в Організації; «своєю неправомірною окупацією Криму Російська Федерація порушила перший принцип міжнародного права, тому цивілізований світ ніколи не визнає заяв Кремля про привласнення українського півострова» [3].

Однозначно з цього приводу висловив свою думку Байден: «...Росія порушила міжнародне право, норми, за якими сучасні країни взаємодіють один з одним, а також суверенітет і територіальну 
цілісність сусідньої України, коли вона вторглася до Криму. Сполучені Штати продовжують підтримувати Україну і ії союзників, і партнерів, як і з самого початку цього конфлікту. У цю похмуру річницю ми підтверджуємо просту істину: Крим - це Україна. Сполучені Штати не визнають і ніколи не визнають анексію півострова Росією, і ми будемо разом з Україною протистояти агресивним діям Pociï» [7].

Безумовно, все що пов'язано з даними подіями є важливим для України, тому дослідження цього напрямку вкрай актуальні та цінні.

Аналіз останніх досліджень і публікацій. Початок активного дослідження становища Криму в світі, дослідження процесів анексії, військової агресії Росії по відношенню до України пав на 2014 рік. Саме 2014-2016 роки були найбільш активними в аспекті дослідження цих подій. Безумовно, це й історичний напрямок, але з часом все більше зявляється публікацій суто політичного руху. Це статті та монографії П.Гай-Нижника, Р.Кополовця, Г.Жирова, О.Задорожного, О.Марусяка, С.Кульчицького, Л.Якубової, Я.Миколаєнка тощо. Дуже цікавим для нашої статті є дисертаційне дослідження Туранського М.О. на тему; «Інформаційно-психологічне забезпечення операції з анексії Криму Російською Федерацією: історичні передумови та практична реалізація» (2020). I хоча воно виконано за спеціальністю 032 «Історія та археологія», але представляє значний науковий інтерес й для політології.

Метою статті є: аналіз процесу формування політичного тригеру «Крим».

Виклад основного матеріалу. Поняття «тригер» (дослівно - «спусковий гачок») може мати різні трактування. «Тригер (від англ. Trigger - спусковий гачок) - це психологічний термін, що означає автоматичну реакцію людського мозку на подразник будь-якого типу. Таким подразником може виступати ситуація, дія, звук, текст і навіть картинка. Тригери працюють на підсвідомому рівні, вони вводять людину в певний стан, викликають конкретні емоції - від радості до гніву, від страху і подиву до жадібності і нестримного бажання» [5].

На мою думку, «потреба у введенні тригерів обумовлена необхідністю аналізу подій, які безпосередньо не пов'язані з політикою, але можуть інтерпретуватися в політичному ключі. Тобто, необхідно описати природу асоціативних зв'язків не з позицій редукції значень або установки семантичних ланцюгів, а з позиції політичної аксіології. Тригер рухає асоціативний ланцюжок по відношенню до певного знаку-моменту, який потім співвідноситься з політичною системою. Це не означає, що ціннісно-політичний тригер не може виступати в якості об'єкта оцінки, різниця лише в тому, що тоді він перестане бути тригером» [9]. Як було визначено раніше «тригер знаходиться в двох положеннях: оцінюваний тригер вже не $є$ тригером, він стає об'єктом оцінки, а неоцінений тригер залишиться тригером і може запустити ланцюжок асоціативних зв'язків, в результаті чого ми отримаємо оцінку індивідом явищ, більш широких, ніж сам тригер» [9].

Я вважаю, що «політичний тригер схильний до повторення. він регулярно зустрічається в текстах, що сприяє його фіксації в свідомості індивіда та активації подальшого сценарію. Він повинен бути пізнаваним, інакше активація не відбудеться, і найпростіший спосіб домогтися впізнаваності - повторення його не тільки в рамках одного тексту, а й в сукупності текстів різних тематик, які часом не відносяться безпосередньо до цього політичному тригеру або зовсім до політики» [9].

Історичні події 2014 року в Криму свідчать про те, що з'явилися озброєні люди у військовій формі, яка не мала розпізнавальних знаків. Ці люди у дуже короткій термін узяли під свій контроль стратегічно важливі споруди та заблокували військові частини Збройних сил України. Як відомо, у березні в Криму було проведено референдум про приєднання до Росії, а з часом півострів офіційно (з боку Росії) став частиною Російської Федерації, що і було закріплено відповідними змінами в конституційно-правовій базі.

Кримський криза викликала велику хвилю негативу по відношенню до Росії, ніж, наприклад, конфлікт в Південній Осетії, який стався раніше. Формально він став приводом для введення перших санкцій проти Росії, що й стало тригером. Правовий статус Криму й досі не закріплений усіма сторонами-учасницями конфлікту, півострів використовує грошову одиницю рубль та є відкритим щодо Росії, проте ні Україна, ні ООН не визнають його частиною РФ.

Статус Криму є прикладом відмінності між «де-юре» $\mathrm{i}$ «де-факто». Опинившись в ситуації, коли право націй на самовизначення стикається з правом держави на територіальну цілісність, міжнародна правова система демонструє свою неспроможність у вирішенні даного питання. Так відбулося з Абхазією та Південною Осетією, з Косово та з Кримом. Легально Крим не $\epsilon$ частиною Росії: проведення референдуму недостатньо, потрібна ще й згода України, якої не було отримано. У той же 
час референдум показав бажання кримчан жити в складі Росії. Навколо цих двох позицій, в цілому, і будується інтерпретація тригеру «Крим», як в сакральному так й у профанному дискурсах.

Варто зауважити, що питання про статус Криму постійно було на порядку денному меді сфери. Питання про статус Криму підіймалося і після розпаду СРСР. Вже тоді в медіасфері можна було знайтта деякі ознаки сучасної інтерпретації тригеру «Крим» в сакральному i профанному дискурсах. Але змінився ланцюжок вихідних подій: кримчани провели референдум про приєднання до Росії, Росія підтримала приєднання Криму, півострів де-факто став російським. Оскільки під час розпаду СРСР кримське питання не було досить гострим, тому й дискурс не став масовим. У 2014 році геополітична ситуація призвела до масового «комунікативному вибуху», який поширився у медіасфері у вигляді «галасу». Тому мова йде не про новий політичний тригер, а про його актуалізацію. І тут слід звернутися к розумінню та типології дискурсу.

У сучасній науці під дискурсом можна розуміти текст; тематику тексту, діалогу або комунікації; діалог або полілог; сукупність мовних актів, мовну ситуацію. При такому розмаїтті трактувань в теорію дискурсу можна було б включити як складову частину всю теорію тексту, але зазвичай поняття «дискурс» $\mathrm{i}$ «текст» розглядають як пересічні.

Види або типи дискурсу можна класифікувати за тематикою - освітній, медичний, релігійний, музичний і т.д.; за джерелами або сферою розповсюдження - дискурс влади, молодіжний дискурс, інтернет-дискурс і т. д .; за цілями - навчальний, дослідницький, маніпулятивний і т. д .; за стилем іронічний, піднесений, поетичний і т. д .; за рівнем - професійний та профанний.

Для початку розглянемо основні моменти, характерні для інтерпретації тригеру «Крим» в сакральному дискурсі.

По-перше, «Крим» сакралізується, головним чином, через історію. Головним аргументом $\epsilon$ «кров, яка була пролита росіянами за цей півострів під час численних російсько-турецьких воєн та під час Першої та Другої світових воєн минулого століття». Особлива увага акцентується на загибелі російських військових під час оборони міста-героя Севастополя, який зіграв ключову роль у відбитті ворожих вторгнень з півдня. У багатьох образах місто Севастополь втілює російську доблесть та велич Чорноморського флоту і є національним символом Росії. Те ж саме підкреслюється в «документальних» картинах: «Крим. Шлях на Батьківщину» (2015), «Битва за Севастополь» (2015), «Крим» (2017), «Битва за Крим» (2020) тощо. Всі ці картини викликали чималий ажіотаж. Зокрема, YouTube позначив «Крим. Шлях на Батьківщину» як картину яка містить шок-контент. Перед переглядом платформа попереджає глядача, що відео може його налякати. Щодо «документальності» подій у картині, то слід вказати що, наприклад, Джен Псакі у 2015 році сказала: «Крим. Шлях на Батьківщину» - це зразок брехливої путінської пропаганди [4]. Симптоматичним $є$ те, що фільм «Крим. Шлях на Батьківщину» наразі показують російським школярам.

Тобто, історія, історичні події є найбільш уживаними інтерпретаціями в сакральному дискурсі. Більшість «сакральних» текстів містять в собі ті чи інші посилання на історичний контекст.

По-друге, у сакральному дискурсі тригер «Крим» викликає асоціативні зв’язки та інтерпретаціїтериторія півострова пов'язана зі священними для російської історії місцями. Вони вважають ії сакральною територією, на якій отримав святе хрещення перший християнський князь Русі Володимир Святославович. I тут ми вже бачимо конфронтацію з профаним дискурсом, оскільки все це не $\epsilon$ достатнім обгрунтуванням для передачі території до складу Росії при відсутності згоди з боку України. Саме сакральність найчастіше виступає в якості лейтмотивів таких текстів. Але, росіяни вважають святість Криму для Росії самодостатнім аргументом, який не вимагає додаткової інтерпретаційної підготовки.

По-третє, сакральний дискурс через тригер «Крим» реалізує конфліктні політичні інтерпретації. Наприклад, Росія веде холодну війну з Заходом, біля кордонів Росії йде справжня війна, і російські люди в небезпеці - отже, їх потрібно захистити. Необхідністю захисту російського населення Криму у фільмі «Крим. Шлях на Батьківщину» В.Путін обгрунтував появу російських військових на території іншої держави. I саме цю позицію ми спостерігали у медіа сфері.

По-четверте, якщо є потреба в захисті, отже, необхідний образ агресора, який існує поза сакрального дискурсу і тому підлягає знищенню. Сакральний дискурс інтерпретує для мережевих спільнот образ ворога, звертаючись до найбільш сакральних подій у вітчизняній історії, наприклад, щодо боротьби фашизмом (по відношенню до України).

Сакральний дискурс політично прирівняв націоналізм до фашизму та розповсюдив його на всіх, хто знаходиться у полі профанному дискурсу. Дуже простий і водночас, дуже вдалий прийом. Фашизм є категорією абсолютного зла в сакральній Великій Вітчизняній війні, а тому застосування 
його в нових суспільно-політичних реаліях гарантує ефект в спільнотах, що реалізують інтерпретації в сакральному дискурсі, a, отже, активно допомагає сакральному дискурсу підтримувати себе. Небезпека, що виходить від ворога і викликає необхідність захистити населення Криму стала головним аргументом у більшості медіатекстів.

По-п’яте, «Крим» став перемогою сакрального дискурсу на тлі масової культури. Конфлікт дав можливість виникненню багатьох мемів, які швидкоо поширилися Інтернетом i, отже, посприяли підтримці сакрального дискурсу. Мова йде про так званих «вежливые люди», «няш-мяш», «Крымнаш» тощо. Як вказує Вікіпедія «Крымнаш» це «невід’ємний елемент символічного ряду ідеологем-символів: «Культ Великой Победы», «Георгиевская лента», «Деды воевали!», «Великий полководець Сталин», «Севастополь - город росийской славы», «Новороссия», «русский мир», «народное ополчение ДНР» (яке рятує від «карателів-фашистів») тощо» [1].

По-шосте, легальність майже не виступає в якості головної теми в медіатекстах, проте активно використовується як допоміжна інтерпретація. Це не означає, що в сакральному дискурсі ставиться під сумнів законність проведеного в Криму референдуму про приєднання до Росії, проте слабкість даного аргументу полягає в тому, що Україна згоди на проведення референдуму не давала. Тому референдум, як факт зробленого народом вибору, використовується лише в сукупності з іншими інтерпретаціями.

По-сьоме, приєднання Криму до Росії розглядається в сакральному дискурсі як чергова військова та геополітична перемога. У вищезгаданій картині «Крим. Шлях на Батьківщини» чимало часу розповідається про унікальність військової операції, проведеної на території півострова, до якої ні Україна, ні Свропа, ні США не були готові. Як правильно заявила керівник програми підтримки демократичних процесів Українського незалежного центру політичних досліджень Юлія Тищенко під час "круглого столу" в Укрінформі: «Для РФ питання анексії Криму є національним надбанням, Крим - головний набуток Путіна у його попередній термін» [2].

У профанному дискурсі інтерпретація тригеру «Крим» $\epsilon$ дещо іншою. Головна увага тут робиться на нелегальність (i, отже, нелегітимність) приєднання Криму. Референдум не визнається, оскільки він не був узгоджений з Україною. Крім того, в деяких джерелах згадується, що Крим не був незалежною державою на час приєднання до Росії. Слід зазначити, що питання про незалежність не було в бюлетенях для голосування. Саме тому, рішення Криму про незалежність не може бути легітимним, тому, що воно не підтверджене референдумом. Втім, розмова про нелегальність приєднання Криму до Росії є лише для підкріпленням даного дискурсу, але ніяк не $є$ його поширенням на сакральний дискурс це відбувається тому, що в сакральному дискурсі правова та політична складова завжди знаходяться в підпорядкованому ставлення до вищих ідентичностей сакрального спрямування. Наприклад, вбивство в сакральному дискурсі - це, в першу чергу, позбавлення людини життя, порушення заповіді тощо, а не злочин відповідно до норм закону. В таких умовах аргумент про нелегальність референдуму та подій, які стали результатом цього референдуму в сакральному дискурсі зіткнеться з такими контраргументами, як, наприклад, Крим земля російської військової слави, на якій проживають «русские» люди, які потребують захисту від фашизму. Саме нелегальність приєднання півострова $€$ головним аспектом серед інтерпретацій тригеру «Крим» в даному дискурсі.

Також, у даному дискурсі викладаються економічні та політичні наслідки приєднання Криму до Росії, причому саме у негативному аспекті. Насамперед, приєднання Криму призвело до санкцій щодо Росії та іiі міжнародної ізоляції (рух від тригера до тригеру в рамках даного дискурсу, в сакральному дискурсі цей зв'язок є слабким).

Крім того, приєднання Криму є коштовною інвестицією, гроші на яку було узято з бюджету Росії. Тут відбувається апелювання до матеріальних цінностей. Але, матеріальні цінності в сакральному дискурсі є вторинними. Загалом, економічна інтерпретація тригеру «Крим» трохи поступається інтерпретації «нелегальність». Тому, економічну інтерпретацію можна вважати умовним лідером, оскільки санкції щодо компаній були введені вже після референдуму та приєднання Криму до Росії.

В аспекті «масової культури» даний дискурс програє сакральному. Меми та інші вірусні картинки, що поширилися Інтернетом, в переважній більшості випадків є продуктом сакрального дискурсу.

Даний дискурс використовує емоційну складову значно менше, ніж сакральний. Емоції представляються на засадах логіки, наприклад, Крим приєднаний нелегально, в Криму розташовуються російські військові, отже, Крим окупований. Саме окупація Криму практична 
єдина емоційна інтерпретація. Тут слід зазначити, що вона характерна, в більшій мірі, для українських 3MI.

У той же час, навіть всередині даного дискурсу немає єдності з приводу статусу Криму, що, безумовно, послаблює його. Відсутність єдності обумовлена самою природою цього дискурсом, який зазнає інакомислення всередині себе. Наприклад, Навальний зазначив, що незважаючи на те, що Крим став частиною РФ супротив норм міжнародного права, українцям не слід сподіватися, що у майбутньому ситуація зминеться на користь України. Тут співвідноситься мораль з легальністю і навіть залежить від неї: легальне - добре та легітимно; нелегальне - погано та нелегітимно.

Таким чином, при інтерпретації тригеру «Крим» даний дискурс стає жертвою власної природи, допускає дискусії та співвідносить події з мораллю. Аргументи хоча і співвіднесені 3 нормами міжнародного права, але не апелюють до вищих ідентичностей $\mathrm{i}$ не $\epsilon$ різноманітними. Сакральний дискурс вихопив «Крим», повторно його актуалізував і навіть вивів в простір «масової культури». I чим більше Крим буде перебувати в складі Росії, тим більше сакральний дискурс буде зміцнювати свою інтерпретацію тригеру «Крим»як вірний. Відповідно будуть вести себе й мережеві спільноти.

Потенціал для виведення спільнот за межі віртуальності у разі інтерпретації тригеру «Крим» ще менше, ніж у випадку з тригерами «санкцій» та «антисанкцій». Сьогодні він реалізується у вигляді свят, мітингів та щодо в річниць приєднання півострова. Така редукція протестного потенціалу відбувається тому, що тригер «Крим» дуже політизований. Наприклад, у випадку 3 «CharlieHebdo» слід говорити про виражений релігійний аспект його інтерпретації (при збереженні політичного), у випадку з «санкціями» та «антисанкціями» виражений економічний ефект. Приєднання ж Криму до Росії - це важлива геополітична подія. Всі інтерпретації - навіть сакральні - йдуть від цього факту. Усі дискурси інтерпретують ціннісно-політичний тригер «Крим» через призму політичної легітимності, але за допомогою різних асоціацій.

Висновки. Можна зробити висновок, що ці дискурси не схильні до згоди між собою, але разом вони здатні забезпечувати «галас». Реальні ж дії відбуваються в рамках якого-небудь одного дискурсу. При цьому боротьба дискурсів між собою не призводить до повноцінної перемоги одного 3 них. Кожен дискурс встановлюе свої певні значення в свідомості індивідів та колективній свідомості спільнот. Всередині сакрального дискурсу існує власний сакрально-профанний дискурс. У той же час, поза профанним дискурсом політика існувати не може.

Слід відзначити, що рух мережевих спільнот за межі віртуальності та перетворення їх в повноцінних політичних акторів залежить від їх розмірів (малі спільноти легше організовуються), а також від інтерпретаційного потенціалу того чи іншого ціннісно-політичного тригеру. Чим більше в тригері закладено суто політичного, тим менше ймовірність реалізації сценарію виведення спільноти за межі віртуальності. I навпаки, якщо в тригері, крім політичного, закладений потенціал для конфліктної інтерпретації, зверненої до вищих ідентичностей (наприклад, релігії в сакральному дискурсі або свободі в профанному дискурсі), тим більшою є ймовірність організації малих мережевих спільнот як політичних акторів.

Перспективний напрямок подальших досліджень. Тригер-аналіз в подальшому виявиться корисним при дослідженні протиборчих дискурсів, оскільки можна очікувати, що ціннісні тригери будуть з'являтися в сучасному політичному полі регулярно.

\section{Бібліографічний список:}

1. Кримнаш - Намкриш: Як змінювалися думки росіян у 2014 році.

URL: https://24tv.ua/krimnash_namkrish_yak_zminyuvalisya_dumki_rosiyan_u_2014_rotsi_n528224

2. Говорити про нелегальність виборів у Криму категорично важливо. Укрінформ, 16.03.2018.

URL: https://www.ukrinform.ua/rubric-crimea/2423465-govoriti-pro-nelegalnist-viboriv-u-krimu-kategoricnovazlivo-ekspert.html.

3. Росії не вдасться спростувати, що Крим це Україна - Британія в ООН. Укрінформ, 18.03.2021.

URL: https://www.ukrinform.ua/rubric-crimea/3210349-rosii-ne-vdastsa-sprostuvati-so-krim-ce-ukraina-britaniav-oon.html.

4. Джейн Псаки. Lb.ua. URL: https://lb.ua/tag/13559_dzhen_psaki

5. Тригери в маркетингу та продажах: що це таке і як їх використовувати. AG MARKETING TEAM.

URL: https://ag.marketing/.

6. Анексія Криму. Головні наслідки для України. Главком. 27.03.2014.

URL: https://glavcom.ua/publications/124364-aneksija-krimu.-golovni-naslidki-dlja-ukrajini-doslidzhennja.html.

7. Байден: Крим - це Україна, ми будемо разом протистояти агресії Росії. Українська правда. 26.02.2021.

URL: https://www.pravda.com.ua/news/2021/02/26/7284859/. 
8. Руденко А., Свчин Д., Дорогань А. Від Тузли до анексії. Чому Росії вдалося захопити Крим у 2014му? Радіо Свобода. 20.02.2021. URL: https://www.radiosvoboda.org/a/chomu-rosiji-vdalosia-zaxopytykrym/31106434.html.

9. Новицький О. Концепти застосування праймінгу та тригеру ЗМІ в політичному житті. Політичне життя, 2020. №4. С.69-74.

\section{References:}

1. Krymnash - Namkrysh: Yak zminiuvalysia dumky rosiian u 2014 rotsi. 24.tv. 05.01.2015

URL: https://24tv.ua/krimnash_namkrish_yak_zminyuvalisya_dumki_rosiyan_u_2014_rotsi_n528224

2. Hovoryty pro nelehalnist vyboriv u Krymu katehorychno vazhlyvo. Ukrinform, 16.03.2018.

URL: https://www.ukrinform.ua/rubric-crimea/2423465-govoriti-pro-nelegalnist-viboriv-u-krimu-kategoricnovazlivo-ekspert.html.

3. Rosii ne vdastsia sprostuvaty, shcho Krym tse Ukraina - Brytaniia v OON. Ukrinform, 18.03.2021. https://www.ukrinform.ua/rubric-crimea/3210349-rosii-ne-vdastsa-sprostuvati-so-krim-ce-ukraina-britania-voon.html.

4. Jennifer Psaki. Lb.ua. URL https://lb.ua/tag/13559_dzhen_psaki.

5. Trigeri v marketinge i prodazhah: chto eto takoe i kak ih ispol'zovat' AG MARKETING TEAM. URL: https://ag.marketing/.

6. Aneksiya Krimu. Golovni naslidki dlya Ukraïni. Glavkom. 27.03.2014. https://glavcom.ua/publications/124364-aneksija-krimu.-golovni-naslidki-dlja-ukrajini-doslidzhennja.html.

7. Bajden: Krim - ce Ukraïna, mi budemo razom protistoyati agresiï Rosiï. Ukrainska Pravda. 26.02.2021. URL: https://www.pravda.com.ua/news/2021/02/26/7284859/.

8. Rudenko A., Evchin D., Dorogan A. Vid Tuzli do aneksiï. CHomu Rosiï vdalosya zahopiti Krim u 2014-mu? Radio Svoboda, 20.02.2021. URL: https://www.radiosvoboda.org/a/chomu-rosiji-vdalosia-zaxopyty-krym/ 31106434.html, 2021.

9. Novic'kij O. Koncepti zastosuvannya prajmingu ta trigeru ZMI v politichnomu zhitti. Politichne zhittya, 2020. №4. C.69-74.

\section{Novytskyi O. O. Formation and Manifestations of the Political Trigger "Crimea"}

The paper is aimed to study the formation and manifestations of the political trigger "Crimea". The historical and value characteristics of the events of 2014 are presented. Direct attention is paid to the analysis of the categorical base, in particular, the concepts of trigger, political trigger, discourse, types of discourse are distinguished. The paper presents the understanding of the status of Crimea in different discourses: sacred and profane. Emphasis is placed on associative connections and interpretations in media texts. It is determined that trigger analysis in the future is useful in the study of opposing discourses, as value triggers will appear more often. It was found that historical events are the most commonly used interpretations in sacred discourse. Most "sacred" texts contain some references to the historical context.

It is determined that the movement of network communities beyond virtuality and their transformation into full-fledged political actors depends on their size (small communities are easier to organize), as well as on the interpretive potential of a value-political trigger. The more the political is in the trigger, the less likely it is to implement the scenario of taking the community beyond virtuality. Conversely, if the trigger, in addition to the political, has the potential for conflicting interpretations that appeal to higher identities, the greater the likelihood of organizing small network communities as political actors.

It is substantiated that the struggle between discourses does not lead to a complete victory of one of them. Each discourse establishes its specific meanings in the minds of individuals and the collective consciousness of communities. Within the sacred discourse there is its own sacred-profane discourse. At the same time, politics cannot exist outside the profane discourse.

Keywords: trigger, mass media, Crimea, occupation, annexation, politics, society, political trigger. 